\title{
Influence of Hydrogel Type and Concentration, and Water Application Rate on some Hydraulic Properties of a Sandy Soil
}

\author{
Ahmed M. Abdallah ${ }^{1}$
}

\begin{abstract}
Water percolation and storage in a model sandy soil amended with four superabsorbent polymers (SAPs) was investigated using drip irrigation with two discharge rates. Superabsorbent polymers (Watersorb, Ag-SAP, Tera-Gel and Water-crystals) were mixed with the soil at three concentrations $[0.2 \%$ or $0.4 \%(\mathrm{~W} / \mathrm{W})$ and control $(0.0 \%)]$. All soil columns received a fixed amount of water at two discharges i.e., 2.0 or $4.0 \mathrm{~L} \mathrm{~h} \mathbf{h}^{-1}$. The percentages of percolated and retained water (relative to total water applied), gravimetric soil water content (G-wc) and bulk density (BD) were determined. All SAPs, at any concentration and water application rate, reduced the percentage of percolated water (PPW) and BD and increased the total soil porosity (TP). The reduction of PPW resulted in increases in soil water storage that were proptional to SAPs concentration. Under low water application rate, SAPs were more efficient as compared with high water application rate, because SAPs had enough time to reach their maximum water absorption capacity (WAC). At a SAPs concentration of $0.4 \%$ and low water application rate, Watersorb, Tera-gel and Ag-sap were acting equally and were best performing, as the G-wc increased by $\mathbf{2 . 6}$ folds compared to control. However, at the high water application rate, SAPs with higher water absorption rate "WAR" (Watersorb) worked best, as its particles swell faster. It can be concluded that, WAC of SAPs is important when irrigation water application rate is low and at high water application rate, WAR would be the most important property allowing SAPs to reach complete water absorption during short irrigation duration.
\end{abstract}

Key words: water application rate, percolation, water absorption capacity, soil water storage, superabsorbent polymers (SAPs)

\section{INTRODUCTION}

The water retention in the root zone is an energetic factor that determines suitability of a soil for agriculture production, and it is affected by rainfall and irrigation (Gao et al., 2014).In sandy soils, rain and/or irrigation water create preferential flow paths. The formation of fingered flows in dry sandy soils, has been shown in several studies (Annaka and Hanayama, 2010; Tullis and Wright, 2007). This phenomenon increases water percolation and markedly reduces water storage in the plant root zone (Wei and Durian, 2014). In rainfed agriculture, due to the poor water retention of light soils and seasonality of rainfall, a significant portion of water is lost via percolation and plants might be subjected to water deficit, even if the precipitation is adequate $(\mathrm{Xu}$ et al., 2015). In irrigated agriculture, in addition to poor soil water storage of sandy soils, much water may be applied and lost by deep percolation(Hüttermann et al., 2009). Not only a significant portion of water is lost by deep percolation, but also, agro-chemicals are leached from the root zone(Yang et al., 2015), leading to economic and environmental problems(Hüttermann et al., 2009; Abobatta, 2018). Therefore, there is an urgent need to promote appropriate management practices that reduce water percolation, increase soil water storage and agro-chemicals use efficiency. Application of suitable soil conditioner to enhance soil properties has become progressively common solution (Bhardwaj et al., 2007). One of the means is the use of super absorbent polymers (SAPs), which absorbs and retains water, consequently, prevents/reduces water loss by percolation and act as a water reservoir in the root zone (Mandal et al., 2016; Thombare et al., 2018). The SAPs are hydrophilic, three-dimensional, cross-linked functional polymeric, which are able to absorb water equivalent to a hundred times of their own weight, and are not dissolved in water (Buchholz, 1998; Sinha, 2018). Such additives, increase the capacity of soil to store and release water when the soil starts to dry (Abobatta, 2018; Dehkordi, 2018; Satriani et al., 2018; Thombare et al., 2018). Therefore, the water might be available to plants rather than being percolated (Yang et al., 2015).

It has been confirmed that SAPs application significantly alters soil physical properties by reducing/preventing water percolation and increasing soil water storage (Wei and Durian, 2014, 2013; Yu et al., 2017, 2011). The swollen hydrogel particles can

DOI: 10.21608/ASEJAIQJSAE.2019.36940

1-Department of Natural Resources and Agricultural Engineering,

Faculty of Agriculture, Damanhour University, 59 Damanhour, Egypt.

Corresponding author at: Department of Natural Resources and

Agricultural Engineering, Faculty of Agriculture, Damanhour University,

Damanhour, 59, Egypt. E-mail address: ph7@ damanhour.edu.eg.

Received May 22, 2019, Accepted June 25, 2019 
modify the soil pore structure; by increasing the small retention pores and decreasing the large drainage pores; resulting in a significant reduction in saturated hydraulic conductivity (Agaba et al., 2010; Han et al., 2013). Moreover, the swollen SAPs form a water-blocking layer between soil particles that effectively clog the water pores, and form a water tank in the upper surface soil layer (Yang et al., 2015). In addition to the increased soil water storage, SAPs also influenced soil porosity, bulk density and structure (Bai et al., 2010; Busscher et al., 2009).

The application of SAPs in agriculture has been intensively studied on different soil types and different plant species. While, laboratory studies compared the swelling behavior (kinetic) and performance of different SAPs, in terms of their concentration, type and application method. Other studies focused on the effect of swollen SAPs under saturated soil conditions. However, the studies conducted under saturated conditions, in our opinion, might overestimate SAPs performance, where it allows SAPs to reach their maximum water absorption capacity (WAC). Under field conditions, in sandy soils, irrigation water mostly moves vertically and its velocity depends mainly on soil properties. Thus, SAPs might not be subjected to saturated environment for a long time and, might not reach their full WAC. In sandy soil, only particles with high water absorption rate (WAR) might absorb significant amounts of water. However, particles with low WAR may not reach their WAC. Therefore, the absorption capacity of SAPs might be affected by water application rate. Consequently, without considering water application rate, SAPs performance may not properly be determined. However, the literature does not provide an explanation for the influence of irrigation water application rate on SAPs performance and irrigation water percolation/storage in SAPs-amended soil. Therefore, the objective of the present study was to analyze irrigation water transport and storage under different irrigation application rates in a sandy soil amended with different SAPs.

\section{MATERIALS AND METHODS}

\section{Soil and SAPs used}

Soil samples were collected from the upper surface soil layer $(0-20 \mathrm{~cm})$ from Elbostan experimental farm station, Faculty of agriculture, Damanhour University. The soil was air-dried and sieved through a 2-mm sieve. Table (1) summarize the main soil physical and chemical characteristics. The soil is sandy, with low organic matter content, weakly alkaline reaction, and non-saline. According to Soil Survey Staff (2014), the soil is classified as Typic Torripsamments. Particles size distribution of the soils were determined using the hydrometer method (Gee and Bauder, 1986). Organic matter (OM) was determined by wet combustion (Nelson and Sommers, 1996) and calculated by multiplying the organic carbon content by a conversion factor of 1.724. Electrical conductivity (ECe) was measured in the saturated soil paste extract. Soil reaction was measured in 1:2.5 soil-water suspension. Total calcium carbonate was measured using the volumetric calcimeter method (Nelson, 1982).

\section{Water absorption characteristics of the SAP}

The most important two water absorption properties were measured for the tested SAP. Water absorption capacity (WAC) and water absorption rate (WAR). The WAC ( $\mathrm{g}$ water $\mathrm{g}^{-1} \mathrm{SAP}$ ) was measured by placing one $\mathrm{g}$ of each SAP in a permeable to water nylon bag, using three replicates (Buchholz, 1998; Yu et al., 2011). The bags containing SAPs were then socked for an hour into a $500-\mathrm{mL}$ beaker containing $400 \mathrm{~mL}$ of irrigation water $\left(0.5 \mathrm{dS} \mathrm{m}^{-1}\right)$, until the equilibrium swelling was reached.

Table 1. The main physical and chemical properties of the used soil.

\begin{tabular}{|c|c|c|c|c|c|c|c|c|}
\hline \multicolumn{3}{|c|}{ Particle size distribution } & \multirow{2}{*}{$\begin{array}{l}\text { USDA } \\
\text { texture } \\
\text { class } \\
\end{array}$} & \multirow{2}{*}{$\begin{array}{l}\text { Bulk Density } \\
\quad\left(\mathrm{Mg} \mathrm{m}^{-3}\right)\end{array}$} & \multirow{2}{*}{$\begin{array}{c}\text { Saturated hydraulic } \\
\text { conductivity } \\
\left(\mathbf{m ~ h}^{-1}\right)\end{array}$} & \multirow{2}{*}{$\begin{array}{c}\mathrm{EC}_{\mathrm{e}} \\
\left(\mathrm{dS} \mathbf{~ m}^{-1}\right)\end{array}$} & \multirow{2}{*}{$\begin{array}{l}\text { OM } \\
(\%)\end{array}$} & \multirow{2}{*}{$\begin{array}{c}\mathrm{CaCO}_{3} \\
(\%)\end{array}$} \\
\hline $\begin{array}{c}\text { Sand } \\
(\%)\end{array}$ & $\begin{array}{l}\text { Silt } \\
(\%)\end{array}$ & $\begin{array}{c}\text { Clay } \\
(\%)\end{array}$ & & & & & & \\
\hline 87.52 & 7.56 & 4.92 & sandy & 1.57 & 1.24 & 3.15 & 0.12 & 3.15 \\
\hline
\end{tabular}

Four cross-linked superabsorbent polymers (SAPs) were used in this study:

(i)Watersorb (0.8-1.0 mm), a potassium-based cross-linked polyacrylamide, (WaterSorb-227 S Church Ave, Fayetteville, AR. USA),

(ii)AG-SAP $(0.8-1.5 \mathrm{~mm})$, co-polymer of acrylic acid \& acrylamide, Potassium based polymer (M² Polymer Technologies, Inc. West Dundee, IL 60118 USA).

(iii)Tera-Gel T- 200 (1.0-2.0 mm),100\% Cross linked Polyacrylate/polyacrylamide copolymer neutralized with potassium salt, (Terawet Green Technologies Inc, California USA), and

(iv)Water crystals (2.0-4.0 mm), a potassium-based cross-linked polyacrylamide (Water crystals, Colorado Springs, Colorado, USA). 
The bags were taken out and the weights of swollen SAPs were determined. The WAC was calculated using the following equation (Rabat et al., 2016; Spagnol et al., 2012a).

$$
W A C=\frac{(W w-W d)}{W d}
$$

Where: WAC, is the water absorption ( $\mathrm{g}$ water $\mathrm{g}^{-1}$ SAP) capacity; Ww and $\mathrm{Wd}$ are the weights (g) of the wet and dry SAPs, respectively.

The water absorption rate (WAR) was determined according to Isik and Kis, (2004) and Yu et al., (2011) by measuring the amount of water absorbed at various times. The WAR of the SAPs was calculated at $0,1,3$, $5,10,20,30,40,50$, and $60 \mathrm{~min}$. At a given time, each SAP with three replications was studied. At the end of each wetting period, the three bags representing a certain SAP were taken out, allowed to drain for three $\min (\mathrm{Yu}$ et al., 2011; Rabat et al., 2016), separately weighted within 15 seconds and absorbed water for each wetting period was calculated.

\section{Experimental set up}

A laboratory experiment was carried out in the Natural Resources and Engineering Department, Faculty of Agriculture, Damanhour University. The installation consisted of a PVC column and dripper simulator (Fig. 1). The dripper simulator was established by tygon tube, emitters and a syringe pump. An Emitter was placed at the top of the soil column to apply water at rate of 2.0 or $4.01 \mathrm{~h}^{-1}$.

Sandy soil samples were air-dried and ground to pass through a $2 \mathrm{~mm}$ sieve. PVC columns $(16 \mathrm{~cm}$ height and an inner cross section area of $78.5 \mathrm{~cm}^{2}$ ), with sealed bottoms and a fine metal mesh at the bottom were used. The bottom of each column was filled with $2 \mathrm{~cm}$ of gravel. A rubber tube was connected to the bottom of the column to collect the percolated water. The SAPsamended air-dried soil was packed into the column then compacted up to $12 \mathrm{~cm}(10 \mathrm{~cm}$ of SAPs-amended soil and $2 \mathrm{~cm}$ of gravel) to reach a desired bulk density of $1.57 \mathrm{Mg} \mathrm{m}^{-3}$ using a hammer (Narjary et al., 2012).

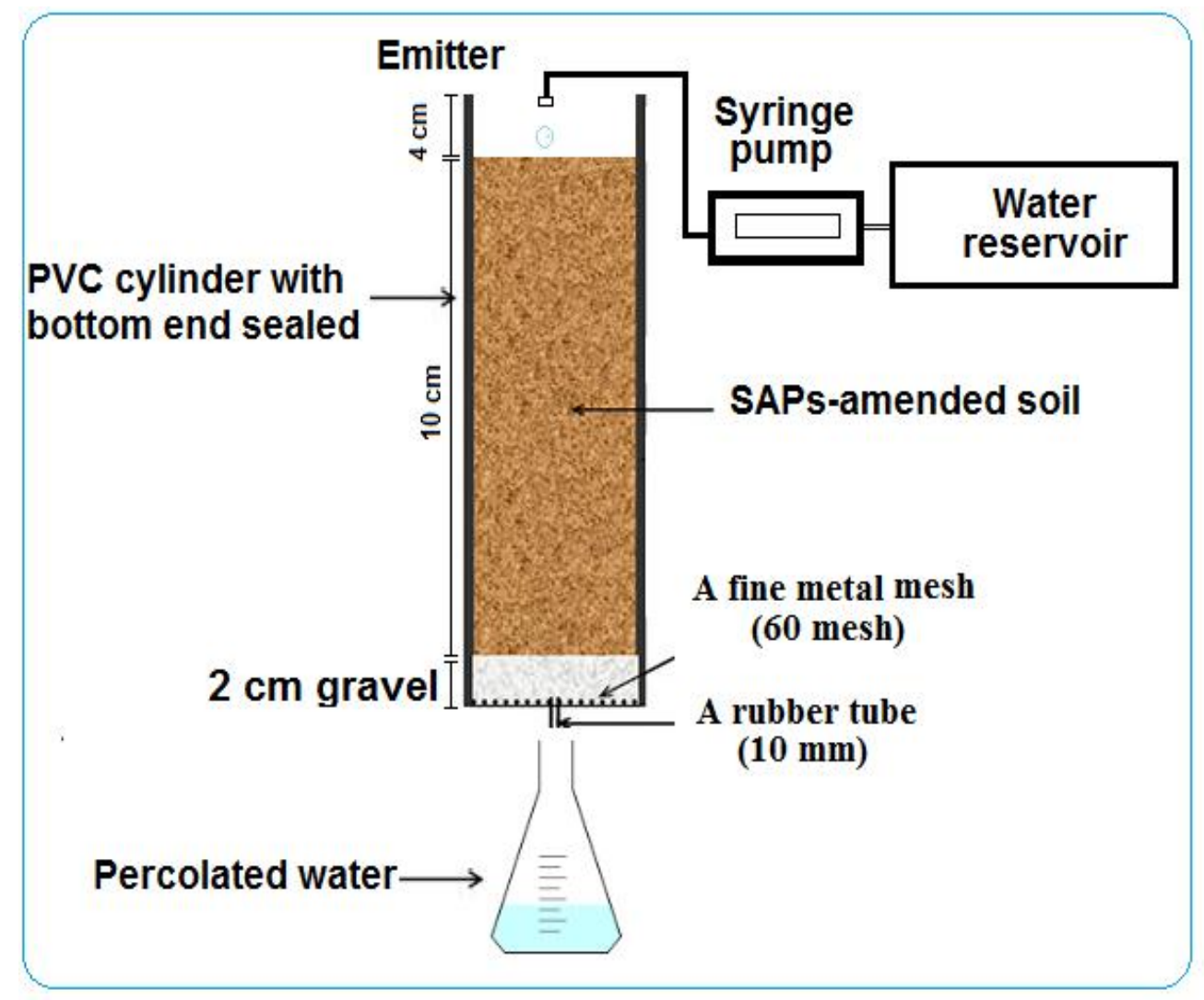

Fig. 1. Schematic of the laboratory set-up. A dispensing emitter is connected to a syringe pump by tygon tube. The syringe pump pervades water to the emitter at a fixed discharge $\left(Q=2.0\right.$ or $\left.4.0 \mathrm{~L} \mathrm{~h} \mathbf{~}^{-1}\right)$ to create a point source drip irrigation. 


\section{SAP-Soil mixture and water application rate}

Each SAP was mixed with the soil at three concentrations $[0.2 \%, 0.4 \%(\mathrm{~W} / \mathrm{W})$ and control $(0.0 \%)]$ with three replicates. Once prepared, the partially filled soil columns were placed right under the emitter. All columns received a fixed amount of irrigation water (two pore volume, $76.5 \mathrm{~mm}$ or $600 \mathrm{~cm}^{3}$ ), at two different application rates i.e., 2.0 or $4.0 \mathrm{~L} \mathrm{~h}^{-1}$. An adequate amount of irrigation water was applied to generate percolation. After terminating irrigation, the top of the column was tied with plastic sheet to avoid water loss by evaporation. The column was allowed to drain completely the gravimetric water. The volume of the percolated water and stored water in the soil columns were recorded for each treatment and their percentage (relative to the volume of total water applied) was calculated. The gravimetric water content (G-wc) for each treatment was determined by oven drying at $105{ }^{\circ} \mathrm{C}$. The increase in soil volume (due to SAPs swelling) was measured, thus soil bulk density and total porosity were calculated. The percentage of percolated water (PPW, the ratio between the volume of water percolated and the volume of total water applied) and the percentage of retained water (PRW, the ratio between the volume of water retained in the soil and the volume of total water applied), were calculated using the following equations:

$$
\begin{aligned}
& \text { PRW }=\frac{(V t-V p)}{V t} \times 100 \% \\
& \text { PPW }=\frac{V p}{V t} \times 100 \quad, \%
\end{aligned}
$$

Where: PPW and PRW are the percentage of percolated and retained water, respectively. Vt and Vp are the volume $\left(\mathrm{cm}^{3}\right)$ of total water applied and percolated, respectively.

\section{Statistical analysis}

The analysis of variance (ANOVA) of the data was conducted using the three-way factorial design in Glmmix procedure in SAS 9.4 (SAS Inc., Cary, NC, USA). Tukey's test was used to compare treatments' means across traits, at significant level of $5 \%(\mathrm{P} \leq$ $0.05)$.

\section{RESULTS}

\section{Water Absorption Capacity and Rate}

The two absorption properties (WAC and WAR) of the different SAPs were affected by SAP type and its particle size. The obtained results (Fig. 2) showed that all tested SAPs absorbed greater amount of water compared to the control treatment. No significant $(\mathrm{P} \leq$ 0.05) differences were recorded among the tested SAPs (Watersorb, Tera-Gel and Ag-SAP); in which the WAC ranged from 153.3 to $156.3 \mathrm{~g}$ water $\mathrm{g}^{-1} \mathrm{SAP}$. However, the WAC of water-crystals SAPs (125 $\mathrm{g}$ water $\mathrm{g}^{-1} \mathrm{SAP}$ ) was significantly lower than those of the others SAPs as shown in Fig. 2.

All SAPs showed similar absorption behavior and patterns at three absorption stages. In the first 0-10 min, that stands for the first absorption stage, a rapid absorption was observed, then the absorption increased slowly (10-30 min) which represented the second absorption stage, followed by nearby steady-state absorption (maximum absorption) for a period of 40-60 min for the last stage, in which SAPs reached absorbtion equlibrium.

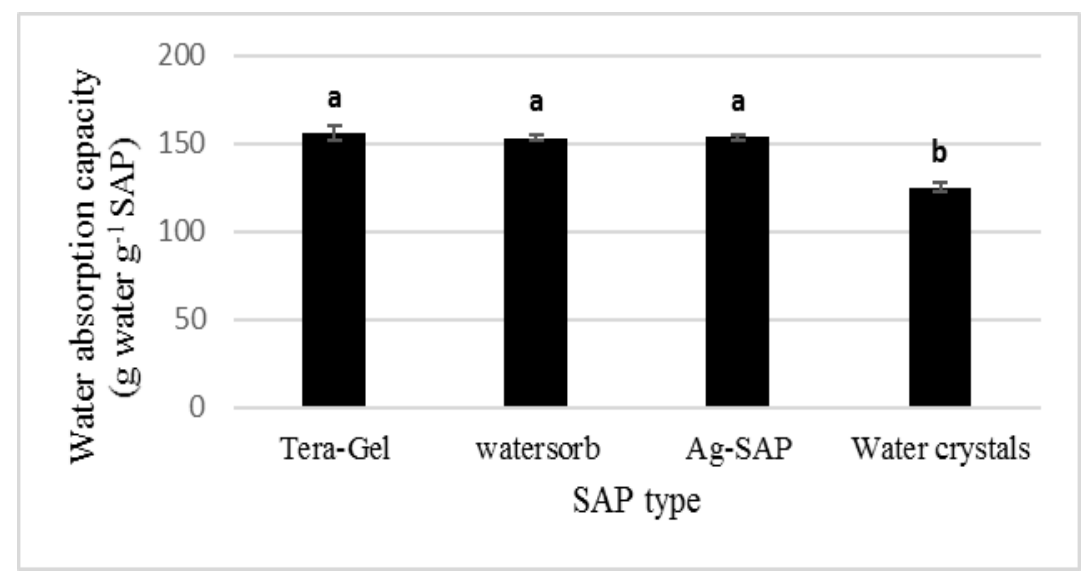

Fig. 2. Water absorption capacity of the SAPs. Data are means \pm standard deviation $(n=3)$.Different letters on the top of bars indicate significant differences between treatments with p-value $\leq 0.05$ (Tukey's test). 


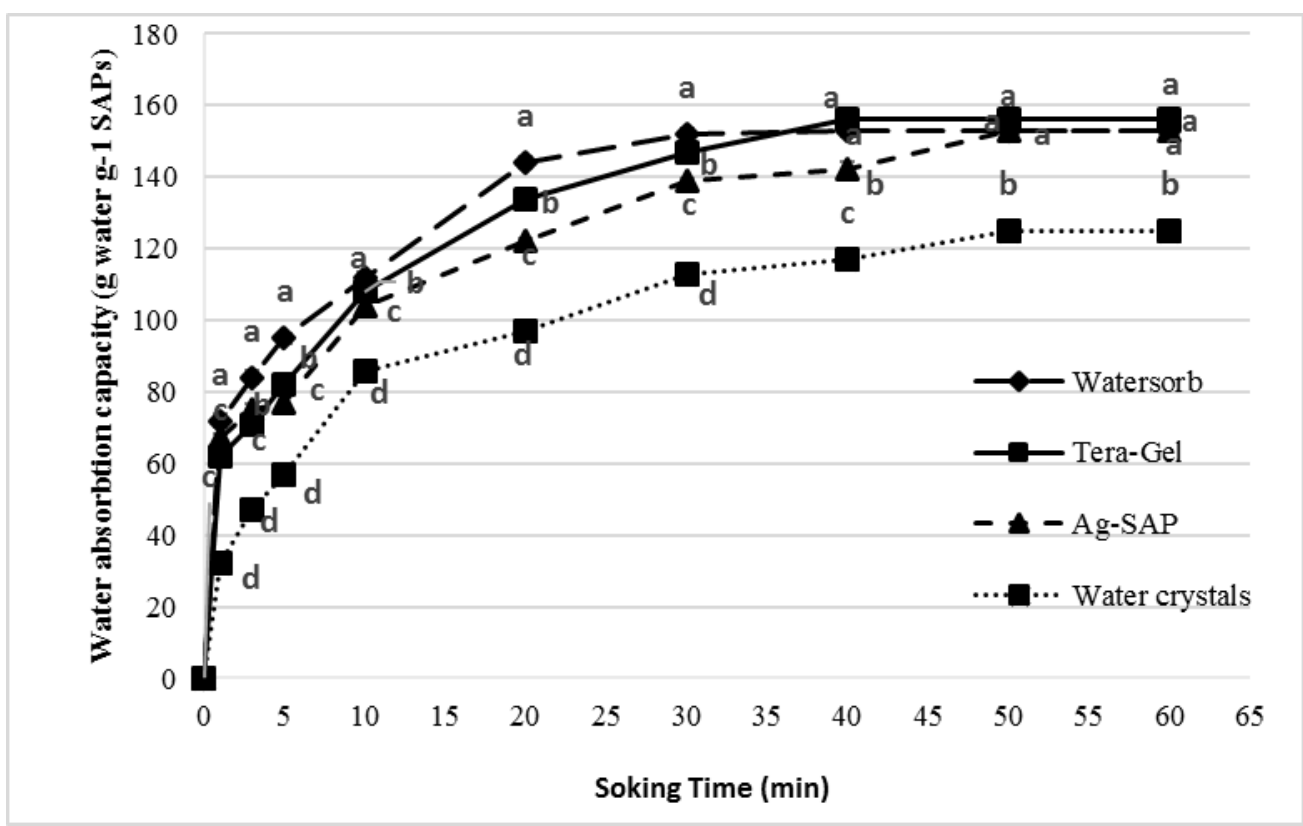

Fig. 3. Water absorption rate (Water absorption capacity, $\mathrm{g}$ water $\mathrm{g}^{-1} \mathrm{SAP}$ as a function of time) of the tested SAPs. Data are means \pm standard deviation $(n=3)$. Different letters indicate significant differences between treatments with p-value $\leq \mathbf{0 . 0 5}$ (Tukey's test). Significant letters apply only within each time of measurement.

The water absorbation rate diffred significantly $(P \sqcap 0.05)$ at the begaining and was affected by the SAP type. For example, the amounts of water absorbed after one min were $72.5,62.2,67.4$ and $32.8 \mathrm{~g} \mathrm{~g}^{-1}$ for Watersorb, Tera-Gel, Ag-SAP and Water crystals, respectively. A similar trend was observed for 3, 5, 10, 15 and $20 \mathrm{~min}$, and the absorbed amount of water followed this order: Watersorb> Tera-Gel> Ag-SAP > Water crystals.The absorption rate of Watercrystals was the slowest among the other SAPs.The WAR for all SAPs, was independent from its WAC (Fig. 3). For example, despite having significant differences in absorption rates, the amount of water absorbed by the different SAPs at the last stage was not significantly affected for theWatersorb, TeraGel and Ag-SAP.

\section{Percolated and Soil Stored Water}

The percolated and stored water in the model sandy soil showed to be a function of SAPs concentration and type, and water application rate.

\section{SAPs concentration}

The percentage of retained water (PRW), percolated water (PPW) and G-wc as a function of SAPs concentration are shown in Fig. (4). The obtained results showed that SAPs application dramatically reduced the PPW compared to the control treatment. Accordingly, the PRW in the soil was increased. Pooling the data for SAP concentration, the results indicated that SAPs application rates significantly $(\mathrm{P} \leq 0.05)$ increased the PRW to $54.9 \%$ and $71.34 \%$ for the SAP concentrations of $0.2 \%$ and $0.4 \%$, respectively, in comparison to $33.4 \%$ of the control.

Therefore, the amount of water percolated was reduced from $66.5 \%$ in the case of the control to $45.01 \%$ and $28.6 \%$ for the SAP concentrations of $0.2 \%$ and $0.4 \%$, respectively. The significant change in the both PPW and PRW, resulted in a significant increase $(P \leq 0.05)$ in G-wc to $49.7 \%$ and $38.4 \%$ for SAP concentrations $0.4 \%$ and $0.2 \%$, respectively, instead of $16.13 \%$ in the case of the control. 


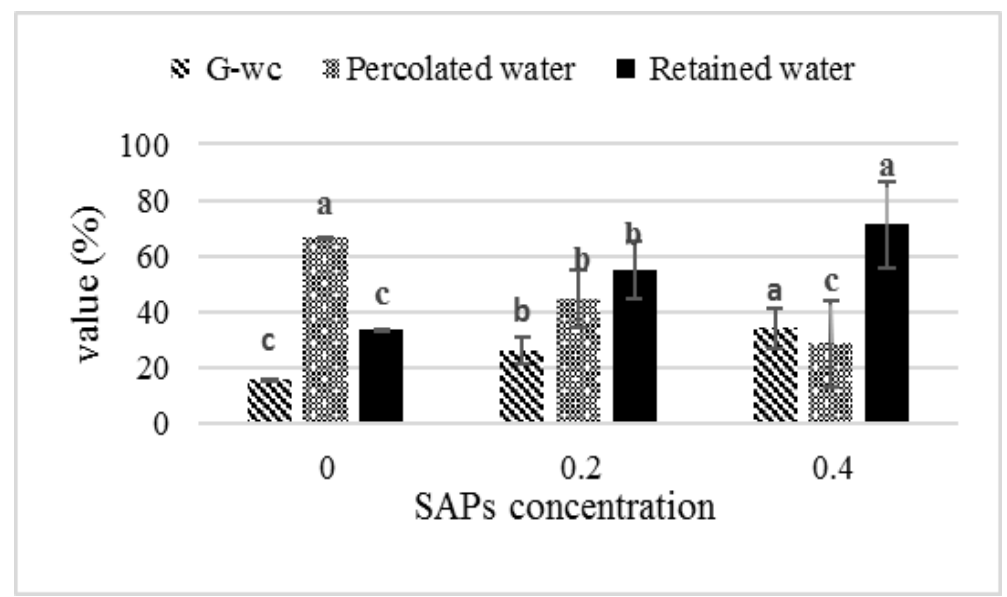

Fig. 4. The percentage of percolated and retained water (relative to total water applied), and Gravimetric water content (G-wc, \%) as affected by SAPs concentration. The data Pooled for SAP concentration treatments. Data are means \pm standard deviation $(n=24)$. Different letters indicate significant differences between treatments with p-value $\leq 0.05$ (Tukey's test). Significant letters apply only within each parameter.

\section{SAP type}

Summing the data for SAP type, the results showed that all tested SAPs significantly affected the downward movement of the water through the soil (Fig. 5). Thus, all SAPs types increased the percentage of water stored in the soil (relative to total water applied) and reduced the water percolation; resulting in a significant increase in G-wc as compared to the control. The highest PRW was recorded for watersorb $(76.8 \%)$, and the lowest value $(33.44 \%)$ was recorded for the control treatment. The highest G-wc (36.8\%) were also observed for Watersorb and the lowest was recorded for the control (16.05\%). However, the highest PPW (66.6\%) and lowest PRW (33.44\%) were recorded for the control treatment. Tera-gel and AG-sap behaved similarly, in which no significant $(\mathrm{P} \leq 0.05)$ difference were recorded in terms of water retention, water percolation and G-wc. Water-crystals was significantly lower than the all tested SAPs, but, still significantly higher than the control, across all tested properties.

\section{Water Application Rate}

The analysis of column water balance showed a significant $(\mathrm{P} \leq 0.05)$ effect of water application rate. Pooling the data for water application rate, the results showed that the low water application rate caused in a significant increase in PRW, and G-wc, while the PPW was significantly reduced, in comparison to the high water application rate (Fig. 6).

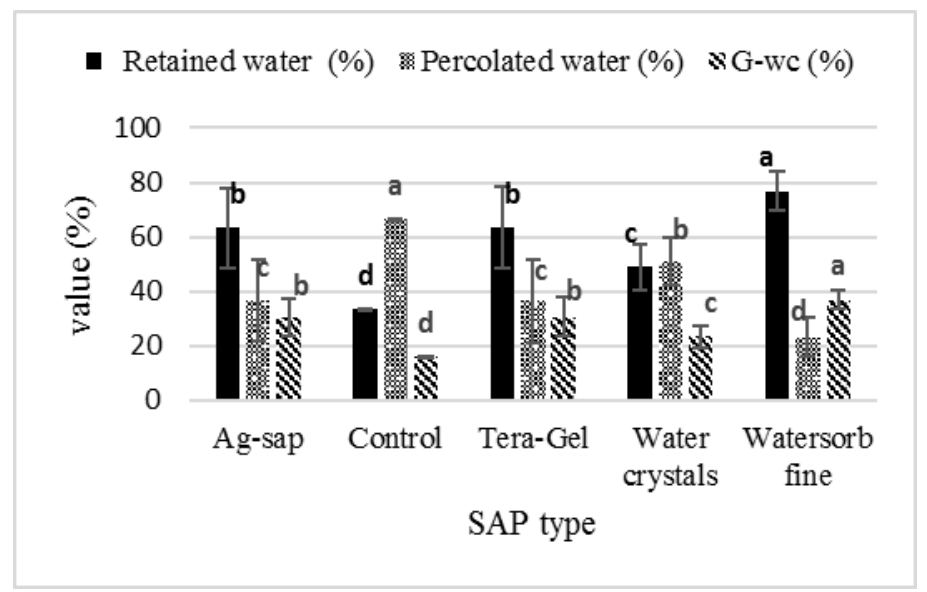

Fig. 5. The relation between SAPs type and the percentage of water retained in the soil, percolated water and Gravimetric water content $(\mathrm{G}-w c)$. The data Pooled for SAP type treatments. Data are means \pm standard deviation $(n=15)$. Different letters indicate significant differences between treatments with $p$-value $\leq 0.05$ (Tukey's test). Significant letters apply only within each measured parameter. 


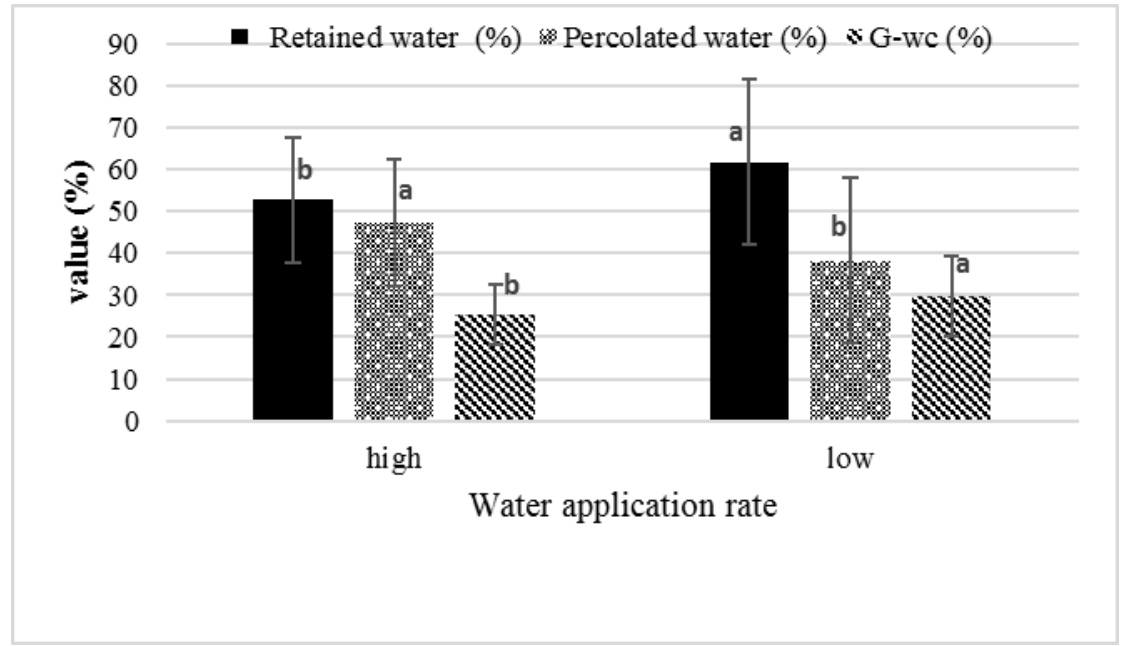

Fig. 6. The relation between water application rate [High $\left(4.0 \mathrm{~L} \mathrm{~h}^{-1}\right)$ and low $\left(2 \mathrm{~L} \mathrm{~h}^{-1}\right)$ ] and the percentage of retained water in the soil, percolated water $(\%)$ and Gravimetric water content $(\mathrm{G}-\mathrm{wc}, \%)$. The pooled data for water application rate. Data are means \pm standard deviation $(n=2 \times 5 \times 3=30)$. Different letters indicate significant differences between treatments with p-value $\leq 0.05$ (Tukey's test). Significant letters apply only within each parameter measured.

The PRW in the case of the low rate was $61.72 \%$ resulted in a G-wc of $29.64 \%$, while $38.2 \%$ of applied water was percolated. However, as the water application rate increased, the PRW and G-wc of the soil reduced to be $50.4 \%$ and $25.32 \%$, respectively.

It is clear that, SAPs were more efficient in reducing percolation at low water application rate. The effect of water application rate was more pronounced (significant) at the higher SAP concentration $(0.4 \%)$, while, at $0.2 \%$ SAP concentration, no significant differences were observed due to water application rate. SAPs were best performing at the high concentration and the low water application rate (Fig. 7). For example, at SAPs concentration of $0.4 \%$, the PRW in the soil was significantly affected by water application rate, in which $71.6 \%$ and $55.42 \%$ of water applied were stored in the soil for the low and high water application rate, respectively. While, at $0.2 \%$, the PRW in the soil was $51.8 \%$ and $49.5 \%$ (with no significant differences) for the low and high application rate, respectively. Similarly, the G-wc at SAP concentration of $0.4 \%$ was $34.4 \%$ and $26.88 \%$ for the low and high water application rate, respectively. Meanwhile, at $0.2 \%$ SAP concentration, the G-wc was $24.8 \%$ and $23.7 \%$ for the low and high application rate, respectively.

\section{The interaction}

The results depicted in Table (2) showed that all SAPs, at any given concentration and any water application rate, significantly $(\mathrm{P} \leq 0.05)$ reduced the PPW and increased PRW. Accordingly, a significant increase in soil G-wc was observed. Watersorb, Tera-gel and Ag-sap at a concentration of $0.4 \%$ and at low water application rate were acting equally and were best performing SAPs. Where, the G-wc increased by 2.6 folds compared to control. It is worth to note that, Watersorb was markedly superior to all tested SAPs, at the high application rate, at both concentrations.

\section{The effect of SAPs on some soil physical properties}

The effect of SAPs type, concentration and water application rate was extended to bulk density (BD), thus total porosity (TP) and volumetric water content (VWC). BD was significantly reduced by $15.3 \%$ and $17.8 \%$ for SAPs concentration of $0.2 \%$ and $0.4 \%$, respectively (i.e., reduced from $1.57 \mathrm{Mg} \mathrm{m}^{-3}$ to 1.33 and $1.29 \mathrm{Mg} \mathrm{m}^{-3}$ for SAPs concentrations of $0.2 \%$ and $0.4 \%$, respectively). Accordingly, TP increased by $22.3 \%$ and $26.0 \%$ for SAPs concentrations of $0.4 \%$ and $0.2 \%$, respectively (i.e., increased from $40.7 \%$ to $49.8 \%$ and $51.3 \%$ for SAPs concentrations of $0.2 \%$ and $0.4 \%$, respectively). By polling the data for the SAP type, all SAPs significantly reduced $\mathrm{BD}$ and increased $\mathrm{TP}$ compared to control. The lowest BD (i.e., reduced by $23.7 \%$ compared to control) and highest TP (i.e., increased by $15.6 \%$ compared to control) were recorded for the Watersorb, meanwhile, the control recorded the highest BD and lowest TP followed by the watercrystals (Fig. 8). However, no differences were recorded between the AG-Sap and Tera-gel. Regarding the interaction, the results presented in Table (2) revealed that the highest decrease in $\mathrm{BD}$ and the greatest increase in TP resulted from Watersorb at $0.4 \%$ and low water application rate. Meanwhile, the control recorded the 
highest $\mathrm{BD}$ and the lowest TP. As expected, the reduction in $\mathrm{BD}$ was proptional to $\mathrm{G}-\mathrm{wc}$, in which a highly significant negative correlation was recorded ( $\mathrm{r}=-$ 0.85 ) between G-wc and TB.

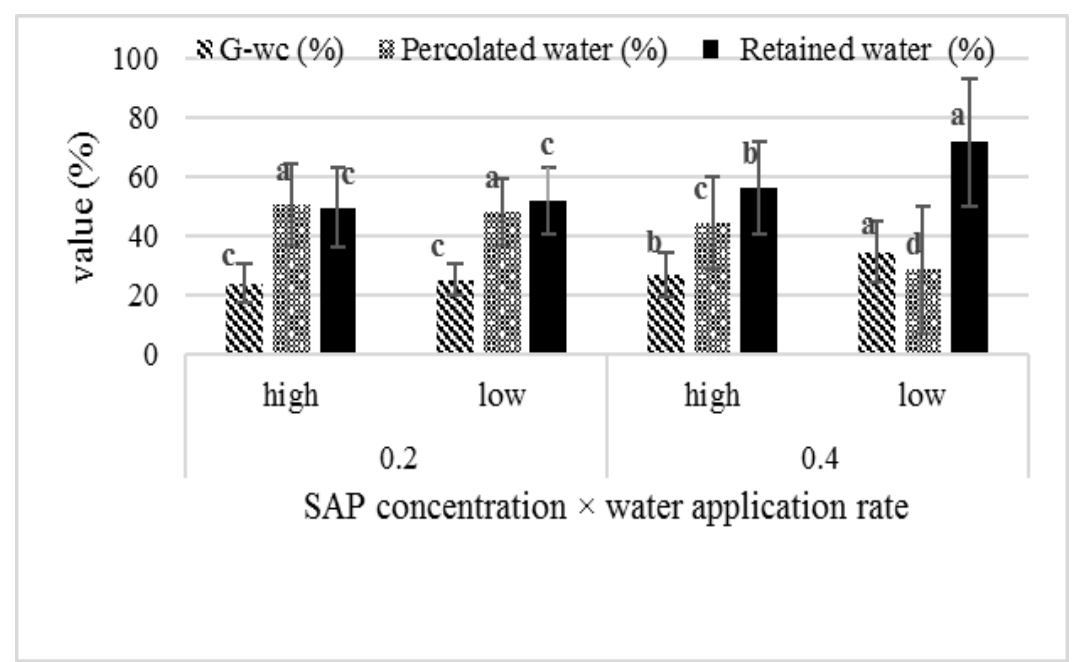

Fig. 7. the interaction between SAPs concentration $(0.4 \%$ and $0.2 \%)$ and water application rate [High $\left(4.0 \mathrm{~L} \mathrm{~h}^{-1}\right)$ and low $\left(2 \mathrm{~L} \mathrm{~h}^{-1}\right)$ ] on the percentage of water retained in the soil, percolated water and Gravimetric water content $(\mathrm{G}-w c, \%)$.Data are means \pm standard deviation $(n=15)$. Different letters indicate significant differences between treatments with p-value $\leq \mathbf{0 . 0 5}$ (Tukey's test). Significant letters apply only within each parameter measured.

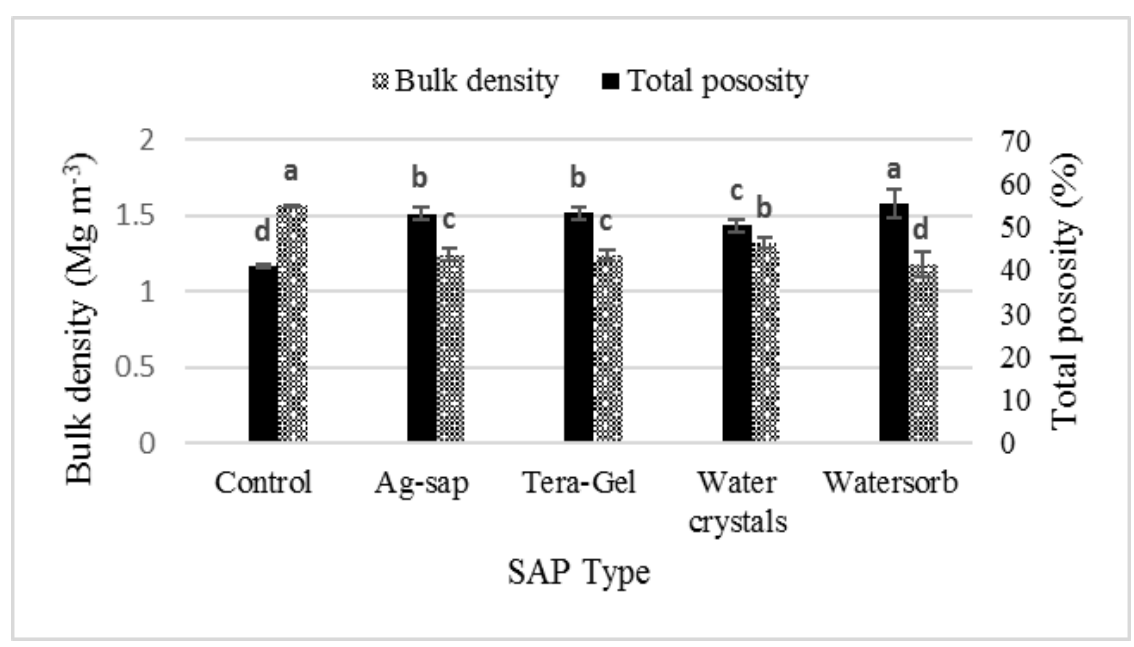

Fig. 8.The effect of SAPs type on soil bulk density $\left(\mathrm{Mg} \mathrm{m}^{-3}\right)$ and total porosity $(\%)$. The data Pooled for SAPs' treatments. Data are means \pm standard deviation $(n=15)$. Different letters indicate significant differences between treatments with $p$-value $\leq 0.05$ (Tukey's test). Significant letters apply only within each parameter measured. 
Table 2. The interaction among SAPs concentration (0.2 and $0.4 \%)$, water application rate [High $\left(4.0 \mathrm{~L} \mathrm{~h}^{-1}\right)$ and low $\left(2 \mathrm{~L} \mathrm{~h}^{-1}\right)$ ] and SAPs type (control, Tera-Gel, Watersorb, Ag-SAP and Water-crystals) on the percentage of water retained $(\%)$, water percolated $(\%)$, gravimetric water content (G-wc, \%), volumetric water content $\left(\mathrm{V}\right.$-wc, \%), bulk density $\left(\mathrm{Mg} \mathrm{m}^{-3}\right)$ and total porosity $(\%)$.

\begin{tabular}{|c|c|c|c|c|c|c|c|c|}
\hline $\begin{array}{c}\text { SAP } \\
\text { concentration } \\
(\%)\end{array}$ & $\begin{array}{c}\text { Water } \\
\text { application } \\
\text { rate } \\
\left(\mathbf{l} \mathbf{h}^{-1}\right)\end{array}$ & $\begin{array}{c}\text { SAP } \\
\text { treatment }\end{array}$ & $\begin{array}{c}\text { Water } \\
\text { Retained } \\
(\%)\end{array}$ & $\begin{array}{c}\text { Water } \\
\text { Percolated } \\
(\%)\end{array}$ & $\begin{array}{l}\text { G-wc } \\
(\%)\end{array}$ & $\begin{array}{l}\text { V-wc } \\
(\%)\end{array}$ & $\begin{array}{c}\text { Bulk } \\
\text { density } \\
\left(\mathrm{Mg} \mathrm{m}^{3}{ }^{3}\right)\end{array}$ & $\begin{array}{c}\text { Total } \\
\text { porosity } \\
(\%)\end{array}$ \\
\hline \multirow{10}{*}{0.2} & \multirow{5}{*}{2.0} & Control & $33.44^{\mathrm{k}}$ & $66.56^{\mathrm{a}}$ & $16.05^{\mathrm{k}}$ & $25.20^{\mathrm{h}}$ & $1.57^{\mathrm{a}}$ & $40.75^{\mathrm{g}}$ \\
\hline & & Ag-sap & $54.39^{\mathrm{g}}$ & $45.61^{\mathrm{e}}$ & $26.11^{\mathrm{g}}$ & $33.42^{\mathrm{e}}$ & $1.28^{\mathrm{bcd}}$ & $51.70^{\text {def }}$ \\
\hline & & Tera-Gel & $50.50^{\mathrm{h}}$ & $49.50^{\mathrm{d}}$ & $24.24^{\text {h }}$ & $31.2^{\text {efg }}$ & $1.29^{\mathrm{bc}}$ & $51.45^{\mathrm{fe}}$ \\
\hline & & Water crystals & $52.11^{\mathrm{h}}$ & $47.89^{\mathrm{d}}$ & $25.01^{\mathrm{h}}$ & $32.27^{\text {ef }}$ & $1.29^{\mathrm{bc}}$ & $51.32^{\mathrm{fe}}$ \\
\hline & & Watersorb & $69.08^{d}$ & $30.92^{\mathrm{h}}$ & $33.16^{\mathbf{d}}$ & $42.76^{\mathrm{b}}$ & $1.29^{\mathbf{b c}}$ & $51.34^{\mathrm{fe}}$ \\
\hline & \multirow{5}{*}{4.0} & Control & $33.44^{\mathrm{k}}$ & $66.56^{\mathrm{a}}$ & $16.05^{\mathrm{k}}$ & $25.20^{\mathrm{h}}$ & $1.57^{\mathrm{a}}$ & $40.75^{\mathrm{g}}$ \\
\hline & & Ag-sap & $50.00^{h}$ & $50.00^{d}$ & $24.00^{\mathrm{h}}$ & $30.24^{\mathrm{fg}}$ & $1.26^{\text {cde }}$ & $52.45^{\text {cde }}$ \\
\hline & & Tera-Gel & $51.44^{\text {h }}$ & $48.56^{\mathrm{d}}$ & $24.69^{h}$ & $30.6^{\mathrm{efg}}$ & $1.24^{\mathrm{cef}}$ & $53.21^{\text {bcde }}$ \\
\hline & & Water crystals & $39.22^{\mathbf{j}}$ & $60.78^{b}$ & $18.83^{\mathbf{j}}$ & $24.98^{\mathrm{h}}$ & $1.33^{\mathbf{b c}}$ & $49.94^{\mathrm{fe}}$ \\
\hline & & Watersorb & $73.17^{\mathfrak{c}}$ & $26.83^{\mathrm{i}}$ & $35.12^{\mathrm{c}}$ & $41.37^{\mathbf{b}}$ & $1.18^{\mathrm{efg}}$ & $55.55^{\mathrm{abc}}$ \\
\hline \multirow{10}{*}{0.4} & \multirow{5}{*}{2.0} & Control & $33.78^{\mathrm{k}}$ & $66.22^{\mathrm{a}}$ & $16.21^{\mathrm{k}}$ & $25.22^{\mathrm{h}}$ & $1.56^{\mathrm{a}}$ & $41.30^{\mathrm{g}}$ \\
\hline & & Ag-sap & $87.83^{\mathrm{a}}$ & $12.17^{\mathrm{k}}$ & $42.16^{\mathrm{a}}$ & $49.61^{\mathrm{a}}$ & $1.18^{\mathrm{efg}}$ & $55.60^{\mathrm{abc}}$ \\
\hline & & Tera-Gel & $87.72^{\mathrm{a}}$ & $12.28^{\mathbf{k}}$ & $42.11^{\mathrm{a}}$ & $50.25^{\mathrm{a}}$ & $1.19^{\mathrm{defg}}$ & $54.9^{\mathrm{abcd}}$ \\
\hline & & Water crystals & $61.33^{f}$ & $38.67^{\mathrm{f}}$ & $29.44^{\text {f }}$ & $37.88^{d}$ & $1.29^{\mathrm{bc}}$ & $51.45^{\mathrm{fe}}$ \\
\hline & & Watersorb & $87.08^{\mathrm{a}}$ & $12.92^{\mathrm{k}}$ & $41.80^{\mathrm{a}}$ & $48.01^{\mathrm{a}}$ & $1.15^{\mathrm{fg}}$ & $56.66^{\mathrm{ab}}$ \\
\hline & \multirow{5}{*}{4.0} & Control & $33.78^{\mathrm{k}}$ & $66.22^{\mathrm{a}}$ & $16.21^{\mathrm{k}}$ & $25.45^{\mathrm{h}}$ & $1.57^{\mathrm{a}}$ & $40.75^{\mathrm{g}}$ \\
\hline & & Ag-sap & $60.94^{f}$ & $39.06^{\mathrm{f}}$ & $29.25^{f}$ & $36.86^{\mathrm{d}}$ & $1.26^{\mathrm{cde}}$ & $52.45^{\text {cde }}$ \\
\hline & & Tera-Gel & $64.61^{\mathrm{e}}$ & $35.39^{\mathrm{g}}$ & $31.01^{\mathrm{d}}$ & $38.77^{\mathrm{cd}}$ & $1.25^{\mathrm{cd}} \mathbf{e}$ & $52.83^{\text {cde }}$ \\
\hline & & Water crystals & $43.33^{\mathbf{i}}$ & $56.67^{\mathrm{c}}$ & $20.80^{\mathbf{i}}$ & $28.49^{\mathrm{g}}$ & $1.37^{\mathbf{b}}$ & $48.30^{\mathrm{f}}$ \\
\hline & & Watersorb & $77.50^{\mathbf{b}}$ & $22.50^{\mathbf{j}}$ & $37.20^{\mathbf{b}}$ & $41.24^{b}$ & $1.14^{\mathrm{g}}$ & $58.08^{\mathrm{a}}$ \\
\hline
\end{tabular}

Different letters indicate significant differences between treatments with p-value $\leq 0.05$ (Tukey’s test). Significance letters apply only within each parameter.

\section{DISCUSSION}

SAPs are known with their ability to absorb water, therefore, SAPs could increase water retention in the soil and reduce water percolation (Ghebru et al., 2007; Han et al., 2010; Yang et al., 2014). It is well established that SAPs performance depend on SAPs' chemistry, formation, soil type and composition of soil solution, and irrigation (Chehab et al., 2017; Orikiriza et al., 2013). In the current study, the effect of irrigation water application rate on water percolation and storage in a sandy soil amended with different SAPs has been investigated.

The ability of SAPs to absorb large amount of water might be attributed to their three-dimensional crosslinked structure, charge density and the hydrophilic functional groups (i.e., amide, hydroxyl, sulfonic, and carboxyl groups) (Dehkordi, 2018; Guilherme et al., 2015). The water absorption properties (WAR and WAC) of SAPs are found to be influenced by SAP types and their particle size. This result is in agreement with those of Ahmed, (2015) and Spagnol et al., (2012b).The high WAR of Watersorb (0.8-1.0 mm) compared with other SAPs, especially, Watercrystals (2$4 \mathrm{~mm}$ ) might be attributed to the size of particles. It has been found that, WAR of SAPs increases with the decrease of SAPs' particle size that results in increases in their specific surface area (Rabat et al., 2016; Yu et al., 2011). For example, Yu et al., (2011) reported that SAPs with fine particles $(<1.5 \mathrm{~mm})$, reached their maximum WAC after 10 to 20 minutes. The WAC of the used SAPs in the current study was relatively low compared to that recorded in several studies (i.e, Akhter et al., 2004; Andry et al., 2009; Yu et al., 2017). This reduction could be attributed to the irrigation water salinity $\left(0.5 \mathrm{dS} \mathrm{m}^{-1}\right)$ that has been used in the present study, while other studies mostly used distilled water (Akhtar et al., 2004; Shahid et al 2012). It is well established that SAPs are highly sensitive to salinity even at the low salinity levels (Banedjschafie and Durner, 2015). For example, Abdallah (2019), found that WAC of SAPs was reduced by about $43 \%$ when water salinity increased to $0.5 \mathrm{dS} \mathrm{m}-1$. 
The very poor water storage and excessive drainage of control soil, observed in this study, might be due to the preferential flow paths (Annaka and Hanayama, 2010; Yang et al., 2015). In such soils, water wets only a thin surface layer, after which the wetting front grows, penetrates the soil and creates water channel, leading to excessive drainage and low soil water storage (Wei and Durian, 2014; Yang et al., 2015). However, in SAPsamended soil, the PPW decreased and the reduction depended on SAP type, SAP concentration and water application rate. It has been shown that, SAPs significantly reduce/prevent the vertical water flow, accordingly increase soil water content. This finding was consistent with the results of Farrell et al. (2013) and $\mathrm{Ni}$ et al. (2010). The observed positive effect of SAPs, in increasing soil water storage, might be due to the water absorbed inside SAPs' particles. Moreover, when water enters into SAPs' network, it forms a gelblocking layer between soil particles, which might reduce the downward movement of water (Hüttermann et al., 2009; Yu et al., 2011).The clogging effects of the swollen SAPs' particles enhance the capillary storage of water in sandy soil pores (Yang et al., 2015). Wei and Durian, (2014) reported that the deeply formed wet-gel layer is efficient in clogging rain water therefore, building water reservoirs in soils. Furthermore, the SAPs' particles during swelling, might modify the pore structure of soil (size and shape), so the water might be altered to flow through nearby dry pores, consequently, increase the capillary storage of water in the soil (Bhardwaj et al., 2007; Han et al., 2013). It could be also due to the reduction in saturated hydraulic conductivity that results from the modification in pores structure and pores blockage by wet SAPs (Agaba et al., 2010; Narjary et al., 2012). In a model sandy soil, Wei and Durian, (2014) attributed the increase in water storage to the swelling capacity of SAPs and clogging by deeply located wet-gel layers more than pore modifications. Therefore, increasing SAPs concentration and selecting the suitable depths are the main practices to increase SAPs efficiency Wei and Durian, (2014). In the current study, the application water at low rate enhanced the performance of SAPs as well. When SAPs' particles are subjected to low water application rate, the amount of stored water in the soil significantly increased in comparison to the high water application rate. SAPs' particles under these conditions had enough time to reach their maximum water absorption capacity, thus prevent the fingered flow and slow down the flow speed in the water channel allowing the formation of wet-gel layers across the soil. Under low application rate, Watersorb, AG-SAP and Tera-Gel showed similar irrigation water balance, because they had enough time to reach their full swelling. On the other hand, when water application rate is high, Watersorb treatment worked best, as, its particles swell faster (had higher WAR) than the other SAPs. In the case of the AG-SAP, Tera-Gel and water crystals,_due to slow swelling (relative to Watersorb), the formation of wet-gel particles was time-consuming and their efficiency largely reduced relative to their efficiency in the case of low application rate. These results are consisted with the results of Yu et al., (2011), in which they reported that SAP type and absorption time and their interactions, significantly affect soil water storage.

SAPs application reduced BD and TP. The G-wc was negatively correlated with $\mathrm{BD} \quad(\mathrm{r}-0.85)$ and positively correlated with TP $(\mathrm{r}=0.85)$. The reduced $\mathrm{BD}$ and increased TP, due to SAPs treatment, agreed with the findings of other research (Busscher et al., 2009; Han et al., 2010; Ruqin et al., 2015). Bai et al., (2010) found a reduction in BD by $9.4 \%$. However, the results contracted with the results reported by Xu et al., (2015) in which they revealed that SAPs application increased soil water storage, but had no significant effect on soil bulk density and TP.

The obtained results showed that in the presence of SAPs particles, still a portion of irrigation water is lost by percolation. The results agreed with those of Wei \& Durian, (2014), in which they reported that not all water applied was retained in the soil. This, mainly might be attributed to that (i) SAPs have a limit of WAC, (ii) water application rate might be higher than WAR and (iii) the modification in pores structure cannot prevent the full formation of the water channel (Wei and Durian, 2014). However, the results of the present study disagreed with the results of Evenari et al., (1971), where they revealed that a SAP-amended soil layer was able to absorb all precipitation, even at a rate of $20 \mathrm{~mm}$ per hour. This inconsistency might be attributed with the difference between rain drop (i.e., mass, diameter and speed) compared to the drops of drip irrigation and to the varying water application rate; where in our study, even the low application rate, was higher than the maximum rain intensity used in the study of Evenari et al.,(1971).

The most important property of superabsorbent polymers (SAPs) is their WAC (Hüttermann et al., 2009). In our opinion, this would be true when irrigation water application rate or rainfall intensity is low. However, if water application (flooded irrigation) or rainfall intensity is high, the WAR would be the most important property. Low water application rate allows SAPs to complete water absorption. Yu et al., (2011) reported that under conditions of flood irrigation, SAPs with small particles should be chosen, due to their fast swelling. Besides increasing SAPs concentration, a key 
solution to increase SAPs performance is to use SAPs with high WAC and high WAR, in addition to reducing water application rate. In irrigated agriculture (drip or sprinkler irrigation), as it is easy to control water application rate, SAPs with high WAC might be best suited. However, in flooded irrigation (water application rate is high) or in rainfed agriculture, where precipitation is not manageable, SAPs with higher WAR might performer better.

\section{CONCLUSION}

Super absorbent polymers (SAPs) significantly reduced the trickling downward movement of irrigation water and increased soil water storage. The effect of SAPs extended to bulk density (BD) and total porosity (TP), in which BD reduced and TP increased. As SAPs particles were subjected to low water application rate, the amount of retained water in the sandy soil significantly increased relative to the high application rate. Under low water application rate, SAPs had enough time to reach its swelling capacity and thus prevent the fingered flow. However, when water application rate is high, SAPs with high swelling rate worked best, since, their particles swell fast. Absorption capacity of SAPs is important when irrigation water application rate is low. However, if water application is high then WAR would be the most important property in order to allow SAPs to complete water absorption during the short irrigation duration. The obtained results indicate that there is an opportunity to improve the performance of SAPs, soil physical and hydraulic properties and environmental sustainability of sandy soils through the use of low water application rate and SAPs of high swelling rate.

\section{ACKNOWLEDGMENTS}

The author thanks Ibrahim Nassar, Professor of Soil Physics, Faculty of Agriculture, Damanhour University, Egypt, for reviewing the manuscript and valuable suggestions. We also thank Mr. Muhammad Wahba Radwan for the English revision of this manuscript.

\section{REFERENCES}

Abdallah, A., 2019. The effect of hydrogel particle size on water retention properties and availability under water stress. International Soil and Water Conservation Research. In press. https://doi.org/10.1016/j.iswcr.2019.05.001

Abedi-Koupai, J., F. Sohrab, and G. Swarbrick. 2008. Evaluation of hydrogel application on soil water retention characteristics. J. Plant Nutr. 31(2): 317-331. doi: 10.1080/01904160701853928.

Abobatta, W. 2018. Impact of hydrogel polymer in agricultural sector. Adv. Agric. Environ. Sci. Open Access 1(2): 59-64. doi: 10.30881/aaeoa.00011.
Agaba, H., L.J.B. Orikiriza, J.F.O. Esegu, J. Obua, J.D. Kabasa, and A. Hüttermann. 2010. Effects of hydrogel amendment to different soils on plant available water and survival of trees under drought conditions. Clean - Soil, Air, Water 38(4): 328-335. doi: 10.1002/clen.200900245.

Ahmed, E.M. 2015. Hydrogel: Preparation, characterization, and applications: A review. J. Adv. Res. 6(2): 105-121. doi: 10.1016/j.jare.2013.07.006.

Akhter, J., K. Mahmood, K.A. Malik, A. Mardan, M. Ahmad, and M.M. Iqbal. 2004. Effects of hydrogel amendment on water storage of sandy loam and loam soils and seedling growth of barley, wheat and chickpea. Plant, Soil Environ. 50(10): 463-469. doi: 10.17221/4059-PSE.

Al-Darby, A.M. 1996. The hydraulic properties of a sandy soil treated with gel-forming soil conditioner. Soil Technol. 9(1-2): 15-28. doi: 10.1016/0933-3630(95)00030-5.

Andry, H., T. Yamamoto, T. Irie, S. Moritani, M. Inoue, and H. Fujiyama. 2009. Water retention, hydraulic conductivity of hydrophilic polymers in sandy soil as affected by temperature and water quality. J. Hydrol. 373(1-2): 177-183. doi: 10.1016/j.jhydrol.2009.04.020.

Annaka, T., and S. Hanayama. 2010. Effects of contact angle on fingered flow during non-ponding infiltration into dry sand layers. Soil Sci. Plant Nutr. 56(3): 366-370. doi: 10.1111/j.1747-0765.2010.00469.x.

Bai, W., H. Zhang, B. Liu, Y. Wu, and J.Q. Song. 2010. Effects of super-absorbent polymers on the physical and chemical properties of soil following different wetting and drying cycles. Soil Use Manag. 26(3): 253-260. doi: 10.1111/j.1475-2743.2010.00271.x.

Banedjschafie, s and Durner, W. 2015. Water retention properties of a sandy soil with superabsorbent polymersas affected by aging and water quality. J. plant Nutr. soil Sci. 178(2002): 798-806.

Bhardwaj, A.K., I. Shainberg, D. Goldstein, D.N. Warrington, and G. J.Levy. 2007. Water retention and hydraulic conductivity of cross-linked polyacrylamides in Sandy Soils. Soil Sci. Soc. Am. J. 71(2): 406. doi: 10.2136/sssaj2006.0138.

Buchholz, F.L. 1998. The structure and properties of superabsorbents polyacrylates. p. 167-221. In Buchholz and Graham. Modern superabsorbent polymer technology, John Wiley Sons Inc. Wiley-VCH.

Busscher, W.J., D.L. Bjorneberg, and R.E. Sojka. 2009. Field application of PAM as an amendment in deep-tilled US southeastern coastal plain soils. Soil Tillage Res. 104(2): 215-220. doi: 10.1016/j.still.2009.02.009.

Chehab, H., M. Tekaya, B. Mechri, A. Jemai, M. Guiaa, Z. Mahjoub, D. Boujnah, S. Laamari, B. Chihaoui, H. Zakhama, M. Hammami, and T. del Giudice. 2017. Effect of the Super Absorbent Polymer Stockosorb ${ }^{\circledR}$ on leaf turgor pressure, tree performance and oil quality of olive trees cv. Chemlali grown under field conditions in an arid region of Tunisia. Agric. Water Manag. 192(October 2017): 221-231. doi: 10.1016/j.agwat.2017.07.013. 
Dehkordi, D. 2016. The effects of Superabsorbent polymers on soils and plants. Pertanika J. Trop. Agric. Sci. 39(3): 267-298.

Dehkordi D. 2018. Effect of superabsorbent polymer on soil and plants on steep surfaces. Water Environ. J. 32(2): 158-163. doi: 10.1111/wej.12309.

El-rehim, H.A.A., E.A. Hegazy, and H.L.A. El-mohdy. 2004. Radiation synthesis of hydrogels to enhance sandy soils water retention and increase plant performance. J. Appl. Polym. Sci. 93, 1360-1371. 93: 1360-1371. doi: 10.1002/app.20571.

Evenari M., Shanan L., T.N. The Negev, the challenge of a desert, Harvard University Press, Cambridge, MA 1971. Harvard University Press.

Farrell, C., X.Q. Ang, and J.P. Rayner. 2013. Water-retention additives increase plant available water in green roof substrates. Ecol. Eng. 52: 112-118. doi: 10.1016/j.ecoleng.2012.12.098.

Ghebru, M.G., E.S. du Toit, and J.M. Steyn. 2007. Water and nutrient retention by aquasoil ${ }^{\circledR}$ and stockosorb $\AA$ polymers. South African J. Plant Soil 24(1): 32-36. doi: 10.1080/02571862.2007.10634778.

Guilherme, M.R., F.A. Aouada, A.R. Fajardo, A.F. Martins, A.T. Paulino, M.F.T. Davi, A.F. Rubira, and E.C. Muniz. 2015. Superabsorbent hydrogels based on polysaccharides for application in agriculture as soil conditioner and nutrient carrier: A review. Eur. Polym. J. 72: 365-385. doi: 10.1016/j.eurpolymj.2015.04.017.

Han, Y.G., P.L. Yang, Y.P. Luo, S.M. Ren, L.X. Zhang, and L. Xu. 2010. Porosity change model for watered super absorbent polymer-treated soil. Environ. Earth Sci. 61(6): 1197-1205. doi: 10.1007/s12665-009-0443-4.

Han, Y., X. Yu, P. Yang, B. Li, L. Xu, and C. Wang. 2013. Dynamic study on water diffusivity of soil with superabsorbent polymer application. Environ. Earth Sci. 69(1): 289-296. doi: 10.1007/s12665-012-1956-9.

Hüttermann, A., L.J.B. Orikiriza, and H. Agaba. 2009. Review application of superabsorbent polymers for improving the ecological chemistry of degraded or polluted lands desertification as a major problem for global sustainability. Clean Soil Air Water 37(7): 517-526. doi: 10.1002/clen.200900048.

Hüttermann, A., M. Zommorodi, and K. Reise. 1999. Addition of hydrogels to soil for prolonging the survival of Pinus halepensis seedlings subjected to drought. Soil Tillage Res. 50(3-4): 295-304. doi: 10.1016/S01671987(99)00023-9.

Isik, B., and M. Kis. 2004. Preparation and determination of swelling behavior of poly(acrylamide-co-acrylic acid) hydrogels in water. J. Appl. Polym. Sci. 94(4): 15261531. doi: 10.1002/app.21074.

Kazanskii, K.S., and S.A. Dubrovskii. 1992. Chemistry and physics of "agricultural" hydrogels. p. 97-133. In Advances in Polymer Science. Springer, Berlin, Heidelberg.
Khodadadi Dehkordi, D., H.A. Kashkuli, A. Naderi, and S.A. Shamsnia. 2013. Evaluation of Superabsorbent super AB A 200 on three corn growth factors affected by drought stress in the spring and summer weather conditions in Khouzestan province. Adv. Environ. Biol. 7(6): 10641073.

Mandal, U.K., K.L. Sharma, K. Venkanna, G.R. Korwar, K.S. Reddy, Pushpanjali, N.N. Reddy, G. Venkatesh, R.N. Masane, and P. Yadaiah. 2016. Evaluating hydrogel application on soil water availability and crop productivity in semiarid tropical red soil. Indian J. Dryl. Agric. Res. Dev. 30(2): 1. doi: 10.5958/2231-6701.2015.00018.4.

Montesano, F.F., A. Parente, P. Santamaria, A. Sannino, and F. Serio. 2015. Biodegradable superabsorbent hydrogel increaseswater retention properties of growing media and plant growth. Agric. Agric. Sci. Procedia 4: 451-458. doi: 10.1016/j.aaspro.2015.03.052.

Narjary, B., P. Aggarwal, A. Singh, D. Chakraborty, and R. Singh. 2012. Water availability in different soils in relation to hydrogel application. Geoderma 187-188: 94101. doi: 10.1016/j.geoderma.2012.03.002.

Ni, B., M. Liu, S. Lu*, L. Xie, X. Zhang, and Y. Wang. 2010. Novel slow-release multielement compound fertilizer with hydroscopicity and moisture preservation. Ind. Eng. Chem. Res. 49(10): 4546-4552. doi: 10.1021/ie9019769.

Orikiriza, L.J.B., H. Agaba, G. Eilu, J.D. Kabasa, M. Worbes, and A. Hüttermann. 2013. Effects of hydrogels on tree seedling performance in temperate soils before and after water stress. J. Environ. Prot. (Irvine,. Calif). 04(07): 713 721. doi: 10.4236/jep.2013.47082.

Rabat, N.E., S. Hashim, and R.A. Majid. 2016. Effect of different monomers on water retention properties of slow release fertilizer hydrogel. Procedia Eng. 148: 201-207. doi: 10.1016/j.proeng.2016.06.573.

Ruqin, F., J. Luo, S. Yan, Y. Zhou, and Z. Zhang. 2015. Effects of biochar and super absorbent polymer on substrate properties and water spinach growth. Pedosphere 25(5): 737-748. doi: 10.1016/S1002-0160(15)30055-2.

Satriani, A., M. Catalano, and E. Scalcione. 2018. The role of superabsorbent hydrogel in bean crop cultivation under deficit irrigation conditions: A case-study in Southern Italy. Agric. Water Manag. 195: 114-119. doi: 10.1016/j.agwat.2017.10.008.

Shahid, S.A., A.A. Qidwai, F. Anwar, I. Ullah, and U. Rashid. 2012. Improvement in the water retention characteristics of sandy loam soil using a newly synthesized poly(acrylamide-co-acrylic acid)/AlZnFe $2 \mathrm{O} \quad 4$ superabsorbent hydrogel nanocomposite material. Molecules 17(8): 9397-9412. doi: 10.3390/molecules 17089397.

Sinha, S. 2018. Biodegradable superabsorbents: METHODS of preparation and application-A review. p. 307-322. In Fundamental Biomaterials: Polymers. Woodhead Publishing.

Soil Survey Staff .2014. Keys to Soil Taxonomy. 12 Edition, United States Department of Agriculture, Natural Resources Conservation Service, Lincoln, 97,pp123-287. 
Spagnol, C., F.H.A. Rodrigues, A.G.V.C. Neto, A.G.B. Pereira, A.R. Fajardo, E. Radovanovic, A.F. Rubira, and E.C. Muniz. 2012a. Nanocomposites based on poly(acrylamide-co-acrylate) and cellulose nanowhiskers. Eur. Polym. J. 48(3): 454-463. doi: 10.1016/j.eurpolymj.2011.12.005.

Spagnol, C., F.H.A. Rodrigues, A.G.B. Pereira, A.R. Fajardo, A.F. Rubira, and E.C. Muniz. 2012b. Superabsorbent hydrogel composite made of cellulose nanofibrils and chitosan-graft-poly(acrylic acid). Carbohydr. Polym. 87(3): 2038-2045. doi: 10.1016/j.carbpol.2011.10.017.

Thombare, N., S. Mishra, M.Z. Siddiqui, U. Jha, D. Singh, and G.R. Mahajan. 2018. Design and development of guar gum based novel, superabsorbent and moisture retaining hydrogels for agricultural applications. Carbohydr. Polym. 185: 169-178. doi: 10.1016/j.carbpol.2018.01.018.

Tullis, B.P., and S.J. Wright. 2007. Wetting front instabilities: A three-dimensional experimental investigation. Transp. Porous Media 70(3): 335-353. doi: 10.1007/s11242-0079103-x.

Verneuil, E., and D.J. Durian. 2011. Permeability of mixed soft and hard granular material: Hydrogels as drainage modifiers. Eur. Phys. J. E 34(7). doi: 10.1140/epje/i201111065-0.

Wei, Y., and D.J. Durian. 2013. Effect of hydrogel particle additives on water-accessible pore structure of sandy soils: A custom pressure plate apparatus and capillary bundle model. Phys. Rev. E - Stat. Nonlinear, Soft Matter Phys. 87(5): 053013. doi: 10.1103/PhysRevE.87.053013.
Wei, Y., and D.J. Durian. 2014. Rain water transport and storage in a model sandy soil with hydrogel particle additives. Eur. Phys. J. E 37(97): 1-11. doi: 10.1140/epje/i2014-14097-x.

Xu, S., L. Zhang, N.B. McLaughlin, J. Mi, Q. Chen, and J. Liu. 2015. Effect of synthetic and natural water absorbing soil amendment soil physical properties under potato production in a semi-arid region. Soil Tillage Res. 148: 31-39. doi: 10.1016/j.still.2014.10.002.

Yang, L., Y. Han, P. Yang, C. Wang, S. Yang, S. Kuang, H. Yuan, and C. Xiao. 2015. Effects of superabsorbent polymers on infiltration and evaporation of soil moisture under point source drip irrigation. Irrig. Drain. 64(2): 275-282. doi: 10.1002/ird.1883.

Yang, L., Y. Yang, Z. Chen, C. Guo, and S. Li. 2014. Influence of super absorbent polymer on soil water retention, seed germination and plant survivals for rocky slopes eco-engineering. Ecol. Eng. 62: 27-32. doi: 10.1016/j.ecoleng.2013.10.019.

Yu, J., I. Shainberg, Y.L. Yan, J.G. Shi, G.J. Levy, and a I. Mamedov. 2011. Superabsorbents and Semiarid Soil Properties Affecting Water Absorption. Soil Sci. Soc. Am. J. 75(6): 2305-2313. doi: 10.2136/sssaj2010.0397.

Yu, J., J.G. Shi, X. Ma, P.F. Dang, Y.L. Yan, A.I. Mamedov, I. Shainberg, and G.J. Levy. 2017. Superabsorbent Polymer Properties and Concentration Effects on Water Retention under Drying Conditions. Soil Sci. Soc. Am. J. 81(4): 889. doi: 10.2136/sssaj2016.07.0231. 


\section{الملخص العربي}

\section{تأثير نوع وتركيز الهيدروجيل ومعدل أضافة المياه علي بعض الخصائص الهيدروليكيه للتربه}

احمد محمد عبد الله

الامتصـــاص مقارنـــة بمعـــل الاضــــافة المرتفــع، لأن

البوليمرات كان لديها الوقت الكافي للوصول إلى أقصــي لوني

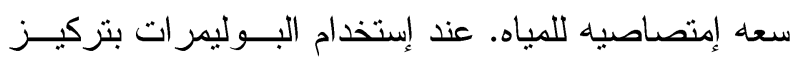

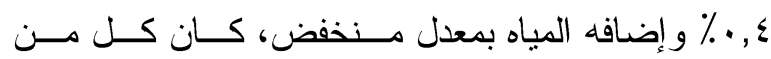
Tera-gel و و Ag-sapatersorb

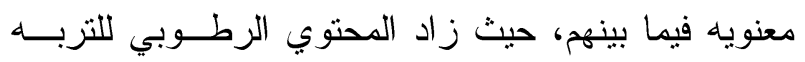
بمقدار T,7 مره مقارنة بالكنترول. عند إضافة المياه بمعدل مرتفع، كان Watersorb هـــو الافضــلـل مقارنــة بجميــع

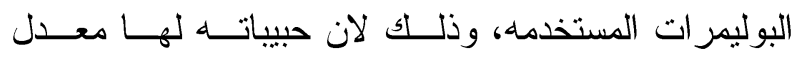
امتصاص أسرع. خلصت الار اسة الي أنه، في حالة أضافة المياه بمعدل منخفض فإن السعه الامتصاصيه للبــــليمرات هي الصفه الاهم. أما في حالة إضافة المياه بمعدل مرتفــع فأن سرعة أمتصاص الماء بواسطة البوليمرات هي الصفه الاهم حيث يسمح ذلك الي الوصول إلى السعه الامتصاصيه للمياه خلال فترة الرى.
تم در اسة ترشح الماء وتخزينه في نموزج لتربة رملية

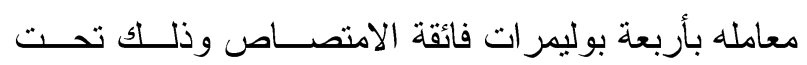

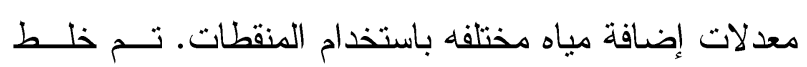

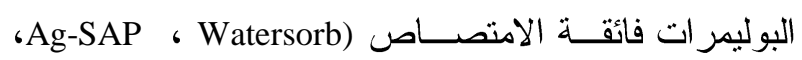
1TeraGel ،Watercrystals

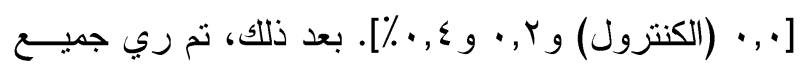

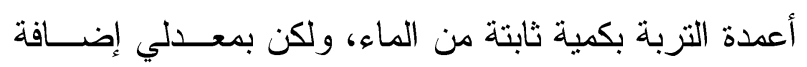
مختلف ( •, r و •,ع لتز/ساعد). ثم تم تقدير النسب المئوية

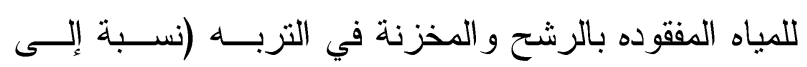

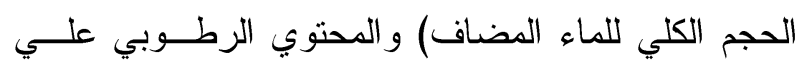
أساس الوزن و الكثافة الظاهرية. أوضحت النتــائج بـــأن جميع البوليمرات، عند أي تركيز وأي معدل إضافه للمياه، أحدثت نقص معنوي في كل من نسبة الماء المفقوده بالرشح و الكثافة الظاهريه. وبالتالي أدت إلي زيادة المسامية الكلية

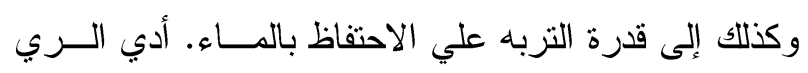

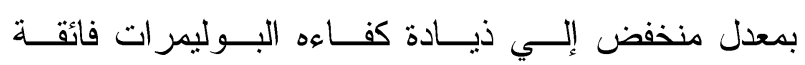

